\title{
Divergent selection for growth rate in the European oyster Ostrea edulis: response to selection and estimation of genetic parameters
}

\author{
Jorge E. Toro ${ }^{1}$, Gary F. Newkirk ${ }^{2}$ \\ ${ }^{1}$ Centro de Investigaciones Marinas, Universidad Austral de Chile, Casilla 567, Valdivia, Chile \\ ${ }^{2}$ Biology Department, Dalhousie University, Halifax, Nova Scotia, Canada B3H 4J1
}

\begin{abstract}
Individual (mass) selection for growth rate was carried out in the European oyster Ostrea edulis (Linne). Oysters from 40 families produced in 1983 were selected on the basis of their live weight after the first growing season. Divergent selection was applied; the High and Low selected group were mated in pairs according to their rank. Twenty-four families were obtained: 6 Low selected and $18 \mathrm{High}$ selected. A total of 6560 spat were individually tagged and brought to the field for $2 \mathrm{yr}$. Shell height and live weight after the first and second growing seasons were analyzed. Statistically significant differences $(p<0.05)$ were found between the offspring of the High and Low selected groups for both traits after both growing seasons. No differences in survival were detected between the families of the 2 selected groups. Heritability estimates for live weight and shell height, after each growing season ranged from $h^{2}=0.112$ to 0.243 . Genetic correlations between the traits were found to be high; $r_{a}=$ 0.963 for the first growing season and $r_{a}=0.995$ for the second growing season
\end{abstract}

\section{INTRODUCTION}

Aquaculture productivity cannot be optimized if the biological potential of the cultured species is not realized. Individuals that have faster growth rate, lower food conversion and higher survival are more economical to raise. Therefore, the introduction of genetic manipulation, in order to make growth rate or survival improvements in aquaculture species, should be considered for routine introduction to hatchery management.

Although polyploidy and hybridization can be useful in bivalve aquaculture (Singh \& Zouros 1981, Thorgaard 1986), exploitation of the additive genetic variance is very important for long-term gain (Newkirk 1980, Mallet 1982). The majority of oyster species are very valuable in economic terms; however, most oysters species have a slow growth rate, requiring at least $3 \mathrm{yr}$ to reach market size. Hence, the application of selective breeding programs in oysters has a great potential, as pointed out by Mahon (1983), Gjedrem (1983) and Gjerde (1986).

Constraints in hatchery facilities normally make it difficult to raise the large number of families required to obtain heritability estimates based on sib analysis.
Also, the reproductive biology of Ostrea species (brooding species) precludes full control of the crosses necessary in these breeding studies. Although sib analysis is useful to obtain estimates of genetic variances and correlations, these data can also be obtained from selection experiments that provide realized heritabilities and correlations and, furthermore, simultaneously initiate the process of producing genetic improvement (Hill 1972). However, non-additive components cannot be estimated.

A selection program requires the estimation of some basic genetic parameters such as heritabilities and genetic correlations for important economic traits. High heritability $\left(\mathrm{h}^{2}\right)$ estimates for a particular trait indicate that a large portion of the trait is associated with additive gene action (Falconer 1981). The presence of genetic correlation implies that the alteration of one trait will cause simultaneous changes in other related traits (Falconer 1981). The changes can be either positive or detrimental and the direction and magnitude of changes will be represented by the sign and degree of correlation between the traits involved.

Reports on genetic parameters in oysters have been mainly restricted to larval and juveniles stages. Lannan (1972) reported heritability estimates for several larval 
traits in Crassostrea gigas; the $\mathrm{h}^{2}$ values were estimated using fullsib analysis and therefore these data may be biassed due to maternal or non-additive genetic effects. Longwell \& Stiles (1973), Haley et al. (1976), Newkirk et al. (1977) and Losee (1978) described heritabilities for larval growth rates in Crassostrea virginica by analyzing full and halfsib families. These $h^{2}$ estimates for growth of larval and juveniles reported ranged between 0.24 and 1.17 suggesting that a large portion of the variance of these traits is genetic variance. Heritability values of 0.20 or larger indicate that genetic progress can easily be achieved through the application of selective breeding programs (Newkirk et al. 1977).

There have been a few descriptions of response to selection in Ostrea edulis (Newkirk \& Haley 1982a, 1983, Ruzzante 1986); however, there is only one report on heritabilities for growth rate in this species (Ruzzante 1986). He gives $h^{2}$ estimates for whole live weight, shell length and shell width for 6-mo-old juveniles with values of $h^{2}=0.09,0.05$ and 0.10 respectively. These estimations were made on a correlated trait, i.e. by using the offspring values at 6 mo when selecting on the basis of whole live weight of 2.5 -yr-old oysters. The response to selection reported in the earlier breeding experiments were always positive. Newkirk \& Haley (1982a) found a large response to selection, with the high-selected groups showing an average weight $23 \%$ higher than the control groups. The results of the second generation were also positive but the selected offspring were only slightly heavier than the control groups (Newkirk \& Haley 1983). The decrease in response in the second generation was attributed to inbreeding. Ruzzante (1986) was able to detect response to selection for growth rate by means of multivariate analysis of variance (MANOVA), using 3 variables (whole live weight, shell length and shell width).

In the present study, a selection experiment with Ostrea edulis was carried out; the response to selection for growth rate, the heritabilities for whole live weight and shell height, and the genetic and phenotypic correlations between traits are reported.

\section{MATERIAL AND METHODS}

A stock of the European oyster Ostrea edulis (Linne) was brought from the Netherlands to Milford, Connecticut (USA) in 1946 by $\mathrm{V}$ Loosanoff. In 1968, O edulis was introduced to eastern Canada (Newkirk \& Haley 1982a). The selection program at Dalhousie University started with a stock of the European oyster produced in the Nova Scotia Department of Fisheries hatchery in 1975 and later, in 1978, a new imported stock from the
University of Maine (USA) was introduced in order to evaluate the Nova Scotia stock (Newkirk 1986).

In 1983, fullsib families were obtained using the single pair mating design; this experiment, reported by Newkirk (1986), produced offspring from pure and hybrid crosses from Nova Scotia and Maine stocks. All fullsib families produced were brought to the field in pearl nets in July 1983. The oysters used as parents in the present study were taken from these 1983 hatchery-produced fullsib families.

The selection of parents was made on the basis of individual live weight after one growing season. Divergent selection (Falconer 1981) was applied in order to obtain High- and Low-selected groups and increase the precision of the heritability estimates (Hill 1971). Oysters whose whole live weight were above +0.7 and under -0.7 standard deviations (SD) from the mean composed the High- and Low-selected groups respectively. The selected individuals were mated in single pairs according to their rank, calculated on the basis of each individual standard score (Newkirk 1986). In the case of the parents the standard score represents the selection intensity.

In March 1987, the oysters were removed from the field and placed in $10^{\circ} \mathrm{C}$ running seawater in the Dalhousie hatchery. After $15 \mathrm{~d}$, the temperature was raised to $15^{\circ} \mathrm{C}$ and cultured microalgae added continuously; the oysters were maintained under these conditions for 2 wk. Fifty-six 8 I buckets (with 7 l of water) were set up, each containing a pair of selected oysters in $22^{\circ} \mathrm{C}$ seawater; the salinity throughout the study was 30 to $32 \%$. Since the selected oysters came from fullsib families, care was taken to avoid the mating of fullsibs in order to reduce inbreeding. A total of 112 oysters were selected distributed in 56 pairs; 38 pairs were from the High-selected group and 18 pairs comprised the Low-selected group.

Oysters were cleaned and the water changed daily, and food, a mixture of Chaetoceros calcitrans, C. gracilis and Isochrysis galbana T-iso, was added twice a day in an approximate concentration of 450000 cells $\mathrm{ml}^{-1}$. Spawning took place between the 4 th and the 7 th week after set up of the pair matings. In 31 buckets there was an early release of recently fertilized eggs. Spat from 24 families were obtained, 18 from the High-selected pairs and 6 from the Low-selected pairs. Ten fullsib families were raised from recently fertilized eggs only, and in 6 pairs offspring were obtained from both eggs and from normal released larvae. The rest of the families were composed of offspring produced from fertilized eggs and premature larvae and normal larvae.

Fertilized eggs, premature larvae or normal larvae released in the spawning buckets were removed daily and a separate culture was set up for each release and for each pair In most cases the fertilized eggs or larvae 
were released during a single day but in some cases a female oyster released its product over 2 to $3 \mathrm{~d}$. The fertilized eggs or larvae were raised in 81 buckets at $24^{\circ} \mathrm{C}$ with aerated filtered seawater In the culture of fertilized eggs every bucket was rinsed daily with hot fresh water and bleach (sodium hypochlorite) followed by seawater. The premature larvae were screened off on a Nitex screen, which was small enough to retain the smallest embryos present $(37 \mu \mathrm{m})$, and then resuspended in filtered $1 \mu \mathrm{m}$ seawater every day (until shelled-larval stages were obtained) instead of every other day as for normal larvae. The size of the screen was increased as the larvae grew. A mixture of Chaetoceros calcitrans and Isochrysis galbana was given every other day to those larvae that reached the swimming stage. Once the larve obtained the setting size (eyed larvae), scallop shells Placopecten magellanicus (Gmelin) were suspended and replaced daily in the larvae cultures to provide setting substrate. These shells containing the spat were then labelled with the bucket (family) number, day of spawn, stage of release and day of set, and then transferred to a common rearing tank at $18^{\circ} \mathrm{C}$ and fed a mixture of cultured algae.

After 3 wk of growth in the hatchery, the scallop shells were cut with a band saw in order to obtain individual spat and then were individually tagged with a number using an epoxy glue as described by Newkirk \& Haley (1982b). The initial weight, including the piece of scallop shell, was recorded. A total of 6560 spat were individually tagged and weighted, corresponding to 24 families; these spat were randomly distributed in 30 pearl nets (3P) at a density of ca 215 ind per net. The nets were transferred to the field in July 1987 and placed in 10 strings of 3 levels in McGrath's Cove. Halifax (Canada) for the next 2 growing seasons.

After the first growing season, live weight, shell height and survival were monitored. The difference between the live weight obtained and the initial weight, which included the piece of scallop shell and the tag, is the actual individual growth at the end of the first growing season. The oysters were held in the laboratory over winter. In July 1988 they were transferred to the field site, distributed randomly in 30 pearl nets (6P) at a density of ca 60 ind. per net. Data collection for the second growing season was carried out in November 1988.

The data analysis was performed using the statistical package SYSTAT 4.0. Analyses of variance (ANOVA), in order to detect any significant difference between the selected groups, were carried out, and Pearson correlations among the parental and between offspring variables were calculated. Offspring-parent weighted linear regression analysis was performed to estimate heritabilities. Analysis of covariance was also carried out to estimate the genetic correlation between the 2 traits. Heritabilities and genetic correlations were estimated by methods described by Falconer (1981) and Becker (1984).

\section{RESULTS}

A total of 2110 and 776 Ostrea edulis juveniles survived after the first and second growing seasons, respectively, from the 24 different fullsib families produced in spring 1987. Means and standard deviations for live weight and shell height were recorded for the offspring of each of the 24 families in November 1987 and November 1988 (Table 1) and for each of the 30 nets in which the juveniles were reared in the field.

The final densities in the nets after the first growing season (S1) varied between 27 to 106 ind. per net with a mean of ca 70 per net. Two nets lacked representation of 2 families, another 9 lacked representation of 3 families (different families) and the rest of the nets had only 20 families represented ( 4 families missing). After the second growing season (S2) the densities in the nets ranged between 13 and 39 ind. per net with an average of ca 25 per net. The net means for live weight of the juveniles ranged from 1.63 to $2.82 \mathrm{~g}$ in $\mathrm{S} 1$ and from 8.98 to $13.51 \mathrm{~g}$ in $\mathrm{S} 2$; the population live weight mean was $2.24 \mathrm{~g} \pm 1.28 \mathrm{SD}$ for $\mathrm{S} 1$ and $10.97 \mathrm{~g} \pm 3.84$ $\mathrm{SD}$ for $\mathrm{S} 2$. The mean of the nets for shell height varied from 22.3 to $31.7 \mathrm{~mm}$ in S1 and from 35.2 to $43.8 \mathrm{~mm}$ in $\mathrm{S} 2$; the population mean for shell height in S1 was $27.35 \mathrm{~mm} \pm 8.19 \mathrm{SD}$ and $39.19 \mathrm{~mm} \pm 8.02 \mathrm{SD}$ in $\mathrm{S} 2$.

The number of oysters per family for $\mathrm{S} 1$ ranged from 20 to 176 for S1 and from 9 to 54 for S2. The survivorship of the offspring in November 1987 was $30 \%$ in the High-selected families and $37 \%$ in the Low-selected families. In November 1988, after the second growing season, the survivorship was $47 \%$ in the High-selected and $53 \%$ in the Low-selected families. Student's t-tests with arcsine-transformed data were performed to compare the survival between the High-and Low-selected families after the first and second growing seasons. In both cases, S1 and S2, no significant differences in survivorship between the High-and Low-selected families was found at $\alpha=0.05$.

Since some families were formed by offspring produced from recently fertilized eggs and also from normal larvae, growth performance and survival between these groups of offspring within families was compared after the first growing season. No significant effect $(p>0.05)$ of stage of release on growth performance or on survival rate was found (Jarayabhand et al. 1988).

There was the possibility that the phenotypic variance differed between those families composed of offspring produced only from fertilized eggs and those 
Table 1. Ostrea edulis. Family means and standard deviations (SD) for live weight (in g) and shell height (in mm) for the offspring generation at the end of the first (S1) and second (S2) growing seasons. N: number alive after each growing season

\begin{tabular}{|c|c|c|c|c|c|c|c|c|c|c|c|}
\hline \multirow[t]{3}{*}{ Group } & \multirow[t]{3}{*}{ Family } & \multicolumn{5}{|c|}{ S1 } & \multicolumn{5}{|c|}{$\mathrm{S} 2$} \\
\hline & & \multicolumn{2}{|c|}{ Weight } & \multicolumn{2}{|c|}{ Height } & \multirow[t]{2}{*}{$N$} & \multicolumn{2}{|c|}{ Weight } & \multicolumn{2}{|c|}{ Height } & \multirow[t]{2}{*}{$N$} \\
\hline & & Mean & $\mathrm{SD}$ & Mean & $\mathrm{SD}$ & & Mean & $\mathrm{SD}$ & Mean & $\mathrm{SD}$ & \\
\hline \multirow[t]{19}{*}{ High } & 55 & 2.94 & 1.57 & 29.78 & 8.53 & 96 & 11.80 & 4.27 & 41.14 & 7.38 & 42 \\
\hline & 58 & 2.26 & 1.17 & 28.72 & 7.54 & 113 & 14.39 & 3.65 & 43.30 & 8.07 & 43 \\
\hline & 61 & 2.06 & 1.24 & 27.45 & 8.30 & 20 & 10.45 & 3.26 & 36.53 & 7.00 & 12 \\
\hline & 69 & 2.16 & 1.15 & 27.08 & 7.80 & 131 & 10.66 & 2.82 & 41.31 & 6.20 & 32 \\
\hline & 71 & 2.89 & 1.59 & 32.18 & 8.19 & 51 & 11.12 & 3.97 & 37.17 & 6.87 & 34 \\
\hline & 72 & 2.09 & 1.17 & 28.96 & 7.58 & 90 & 10.46 & 3.29 & 38.07 & 6.47 & 39 \\
\hline & 75 & 2.43 & 1.61 & 28.93 & 9.03 & 28 & 11.04 & 4.41 & 37.38 & 5.76 & 18 \\
\hline & 80 & 2.10 & 1.27 & 26.90 & 8.69 & 176 & 10.33 & 3.41 & 40.88 & 7.00 & 54 \\
\hline & 84 & 2.06 & 1.09 & 27.12 & 7.81 & 139 & 9.46 & 2.86 & 37.34 & 6.45 & 35 \\
\hline & 88 & 2.27 & 1.14 & 26.69 & 8.13 & 83 & 11.18 & 4.31 & 38.30 & 9.77 & 26 \\
\hline & 101 & 1.94 & 0.90 & 26.23 & 6.48 & 22 & 11.44 & 4.21 & 39.55 & 10.05 & 9 \\
\hline & 102 & 2.93 & 1.36 & 28.44 & 8.34 & 115 & 9.27 & 3.86 & 37.35 & 7.82 & 37 \\
\hline & 103 & 2.08 & 1.06 & 25.77 & 7.19 & 65 & 11.53 & 3.53 & 36.65 & 7.18 & 23 \\
\hline & 105 & 2.41 & 1.27 & 28.46 & 8.50 & 109 & 9.50 & 3.40 & 40.26 & 9.24 & 41 \\
\hline & 107 & 2.69 & 1.29 & 27.09 & 8.24 & 104 & 12.44 & 4.06 & 39.21 & 8.55 & 38 \\
\hline & 109 & 2.41 & 1.17 & 27.66 & 8.27 & 116 & 12.82 & 3.84 & 42.14 & 6.70 & 35 \\
\hline & 110 & 2.44 & 1.23 & 27.41 & 7.20 & 84 & 13.54 & 4.37 & 40.47 & 9.49 & 34 \\
\hline & 112 & 2.21 & 1.44 & 27.87 & 8.90 & 37 & 10.66 & 4.47 & 42.04 & 8.83 & 23 \\
\hline & Mean & 2.36 & 1.28 & 27.83 & 8.14 & 1579 & 11.30 & 3.98 & 39.68 & 7.88 & 576 \\
\hline \multirow[t]{7}{*}{ Low } & 32 & 1.83 & 1.20 & 26.21 & 8.21 & 115 & 9.33 & 2.91 & 37.50 & 8.26 & 34 \\
\hline & 33 & 2.12 & 1.30 & 26.33 & 8.64 & 148 & 10.71 & 3.28 & 39.42 & 8.87 & 52 \\
\hline & 34 & 1.79 & 1.10 & 25.73 & 8.84 & 127 & 10.79 & 3.10 & 38.02 & 7.06 & 39 \\
\hline & 36 & 1.88 & 1.14 & 25.32 & 6.76 & 25 & 9.90 & 3.60 & 36.05 & 7.24 & 18 \\
\hline & 37 & 2.33 & 1.28 & 28.49 & 6.18 & 33 & 8.18 & 3.13 & 34.57 & 7.67 & 21 \\
\hline & 97 & 1.43 & 0.77 & 24.17 & 7.02 & 83 & 10.03 & 2.94 & 38.05 & 9.12 & 36 \\
\hline & Mean & 1.87 & 1.17 & 25.91 & 8.16 & 531 & 10.03 & 3.21 & 37.76 & 8.25 & 200 \\
\hline \multicolumn{2}{|c|}{ Population mean } & 2.24 & 1.28 & 27.35 & 8.19 & 2110 & 10.97 & 3.84 & 39.19 & 8.02 & 776 \\
\hline
\end{tabular}

with offspring from different stages of release. To test for this or other sources of heteroscedasticity Bartlett's test for homogeneity of variances (Sokal \& Rohlf 1981) were carried out with log-transformed data on live weight and shell height for the first and second growing season. The variances were homogenous in all cases $(p>0.05)$.

ANOVAS were carried out with individual data on live weight and shell height for the first and second growing season (Table 2) in order to detect differences in growth between the offspring of the High-selected parents and those of the Low-selected parents. In the model

$$
\mathrm{Y}_{\mathrm{ij}}=\mathrm{u}+\mathrm{NET}_{\mathrm{j}}+\mathrm{GROUP}_{\mathrm{j}}+\mathrm{NET}_{\mathrm{i}} \times \mathrm{GROUP}_{\mathrm{j}}+\mathrm{e}_{\mathrm{ij}}
$$

log-weight or log-height were considered as dependent variables $(\mathrm{Y})$; $\mathrm{u}$ the population mean and the dummy variables $\mathrm{NET}_{1}$ and Group $_{j}$ were considered as the independent variables. The random effect $N E T_{i}$ (where $i=1,2,3, \ldots 30$ ) was introduced into the model to control for environmental variance among the different nets. The variable GROUP took the value 0 if the oyster was an offspring of High-selected parents and 1 if the oyster was from Low-selected parents. The term NET $_{1} \times$ GROUP $_{j}$ was included to test for genotype-environment interaction. The term $e_{i j}$ was the error term.

No significant interaction effect was found at $\alpha=$ 0.10 in the first growing season; for the second growing season the interaction term was not estimated due to the presence of too many missing cells (Table 2). A highly significant Group effect ( $p<0.01)$ was detected for the 2 dependent variables (live weight and shell height) during the first and second growing seasons. Therefore, for both traits (live weight and shell height) there was a clear discrimination between the High- and Low-selected groups (Table 2). The NET effect was also significant during both growing seasons.

The response to selection in both traits (live weight and shell height) suggests that the genetic correlation coefficients are positive between these traits. The genetic correlations between the 2 characters were estimated using the geometric method according to Becker (1984). The estimated phenotypic, genetic 
Table 2. Ostrea edulis. Mean squares (MS) for live weight and shell height after the first and second growing seasons

\begin{tabular}{|c|c|c|c|c|c|c|}
\hline \multirow[t]{2}{*}{ Effect } & \multicolumn{3}{|c|}{ First growing season } & \multicolumn{3}{|c|}{ Second growing season } \\
\hline & df & $\begin{array}{l}\text { Weight } \\
\text { MS }\end{array}$ & $\begin{array}{c}\text { Height } \\
\text { MS }\end{array}$ & $\mathrm{df}$ & $\begin{array}{l}\text { Weight } \\
\text { MS }\end{array}$ & $\begin{array}{c}\text { Height } \\
\text { MS }\end{array}$ \\
\hline Net & 29 & $1.614^{\cdots}$ & $0.463^{\cdots}$ & 29 & $0.103^{\bullet}$ & $0.299 \cdots$ \\
\hline Group & 1 & $28.124^{\cdots}$ & $2.479^{\cdots}$ & 1 & $0.426^{\cdots}$ & $1.882 \cdots$ \\
\hline Net $\times$ Group & 29 & 0.556 & 0.105 & 29 & - & - \\
\hline Residual & 2050 & 0.413 & 0.107 & 745 & 0.044 & 0.134 \\
\hline
\end{tabular}

(additive) and environmental correlation coefficients for the first and second growing season are presented in Table 3. The phenotypic and genetic correlation. coefficients between the first and second growing season for the traits live weight and shell height are given in Table 4.

Table 3. Ostrea edulis. Phenotypic $\left(\mathrm{r}_{\mathrm{p}}\right)$, genetic $\left(\mathrm{r}_{\mathrm{i}}\right)$ and environmental ( $\mathrm{re}$ ) correlations between live weight and shell height after the first (S1) and second (S2) growing seasons

\begin{tabular}{|lccc|}
\hline Season & $\mathrm{r}_{\mathrm{p}}$ & $\mathrm{r}_{\mathrm{a}}$ & $\mathrm{r}_{\mathrm{e}}$ \\
\hline S1 $(6 \mathrm{mo}$ old $)$ & 0.850 & 0.963 & 0.839 \\
S2 $(18$ mo old $)$ & 0.740 & 0.995 & 0.670 \\
\hline
\end{tabular}

Several methods are available to estimate heritability $\left(\mathrm{h}^{2}\right)$ of a trait, e.g. full and halfsib analysis, and regression of offspring on one or both parents (Falconer 1981). In the present study, regression of offspring on midparent values was performed. Ostrea edulis is a species that is able to change sex during its lifetime (Walne 1979), thus it is safe to assume that the phenotypic variance of the traits involved is the same in both sexes.

A standard score for the offspring was calculated for each growing season and then averaged for each of the 24 families. Standard scores of the parents were calculated for each growing season and the mid-parent values reckoned. Heritability estimates of a selected trait by means of offspring-parent regression should be made comparing successive generations at the same stage of their life cycle. In this study the offspring and the parental scores for live weight and shell height have been calculated for their first and second growing

Table 4. Ostrea edulis. Phenotypic $\left(\mathrm{r}_{\mathrm{p}}\right)$, genotypic $\left(\mathrm{r}_{\mathrm{a}}\right)$ correlation between the first and second growing seasons for the traits live weight and shell height $(n=776, p=0.001)$

\begin{tabular}{lcc|}
\hline Trait & $\mathrm{r}_{\mathrm{p}}$ & $\mathrm{r}_{\mathrm{a}}$ \\
\hline Live weight & 0.48 & 0.72 \\
Shell height & 0.70 & 0.75 \\
\hline
\end{tabular}

season. Since the time of setting of the spat had a significant effect on the values of both traits in the first growing season, the day of set was included as a covariate in the estimation of the standard scores. The number of offspring per family varied among families (Table 1), therefore a weighting factor according to the family size was calculated in order to obtain unbiassed estimates of the regression coefficient. The weighting was described by Kempthorne \& Tandon (1953) and modified by Falconer (1963) in order to give families of size 1 a weighting factor of 1 .

The $\mathrm{h}^{2}$ estimates and the standard errors (SE) for the traits live weight and shell height after the first and second growing seasons are given in Table 5. For shell height there was a significant F-ratio $(p<0.01)$ for the regression coefficient, indicating that the heritability estimate is actually significantly different from zero. The coefficients of determination $\left(r^{2}\right)$ ranged between

Table 5. Ostrea edulis. Heritability estimates $\left(\mathrm{h}^{2}\right)$ and standard errors (SE) of live weight and shell height at 6 (S1) and 18 (S2) mo of age

\begin{tabular}{|lcccccc|}
\hline Trait & \multicolumn{3}{c}{$\mathrm{S} 1$} & & & $\mathrm{~S} 2$ \\
& $\mathrm{~h}^{2}$ & & $\mathrm{SE}$ & $\mathrm{h}^{2}$ & & $\mathrm{SE}$ \\
\hline Live weight & 0.136 & \pm & 0.118 & 0.243 & \pm & 0.202 \\
Shell height & 0.112 & \pm & 0.041 & 0.194 & \pm & 0.070 \\
\hline
\end{tabular}

0.27 and 0.53 , suggesting that around $40 \%$ of the variance has been explained by the regression model.

The pattern of response is shown in Figs. 1 and 2. The selection intensity of parents against the mean standard score of the offspring of each of the 24 families was plotted for each trait in the first and second growing seasons.

\section{DISCUSSION}

The estimation of genetic parameters (heritability and genetic correlation) in traits such as live weight and shell height of juveniles and adults is essential in a 
breeding program to enhance the growth rate of oysters. Heritability estimates are essential for the purpose of predicting the genetic gain by selection.

Growth rate is generally considered to be a trait of low to moderate heritability in oysters. Estimates of 0.09 for live weight and 0.05 for shell height have been obtained for Ostrea edulis (Ruzzante 1986) and $\mathrm{h}^{2}=$ 0.24 for larval growth in Crassostrea virginica (Longwell 1976). Besides the $h^{2}=0.467$ for shell width in 3 yr-old pearl oyster Pinctada fucata martensii (Wada 1986), there have only been reports of heritability estimates for growth rate traits on oysters under 6 mo old, most of them for larval traits (Lannan 1972, Newkirk et al. 1977, Losee 1978). Such estimates are in general not valid for making selection decisions at greater age (Newkirk 1981, Haley \& Newkirk 1982).

The use of divergent selection improves the precision of the heritability estimate (Falconer 1981). By choosing the most extreme phenotypes the variance of the independent variable is increased (Hill 1972). This allows us to obtain more information about the regression (Falconer 1981) by decreasing the standard error of the $h^{2}$ estimate (Hill \& Thompson 1977).
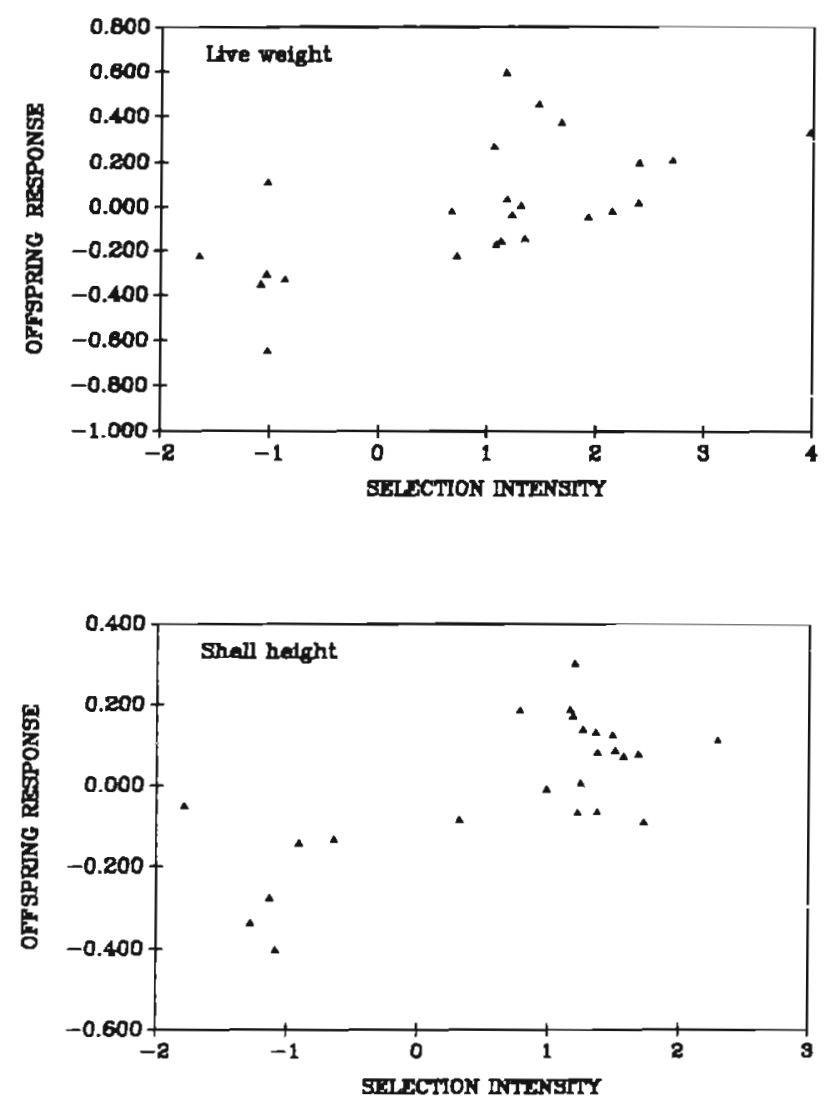

Fig. 1. Ostrea edulis. Plot of standardized response to selection of offspring against selection intensity of parent oysters for the traits live weight and shell height after the first growing season
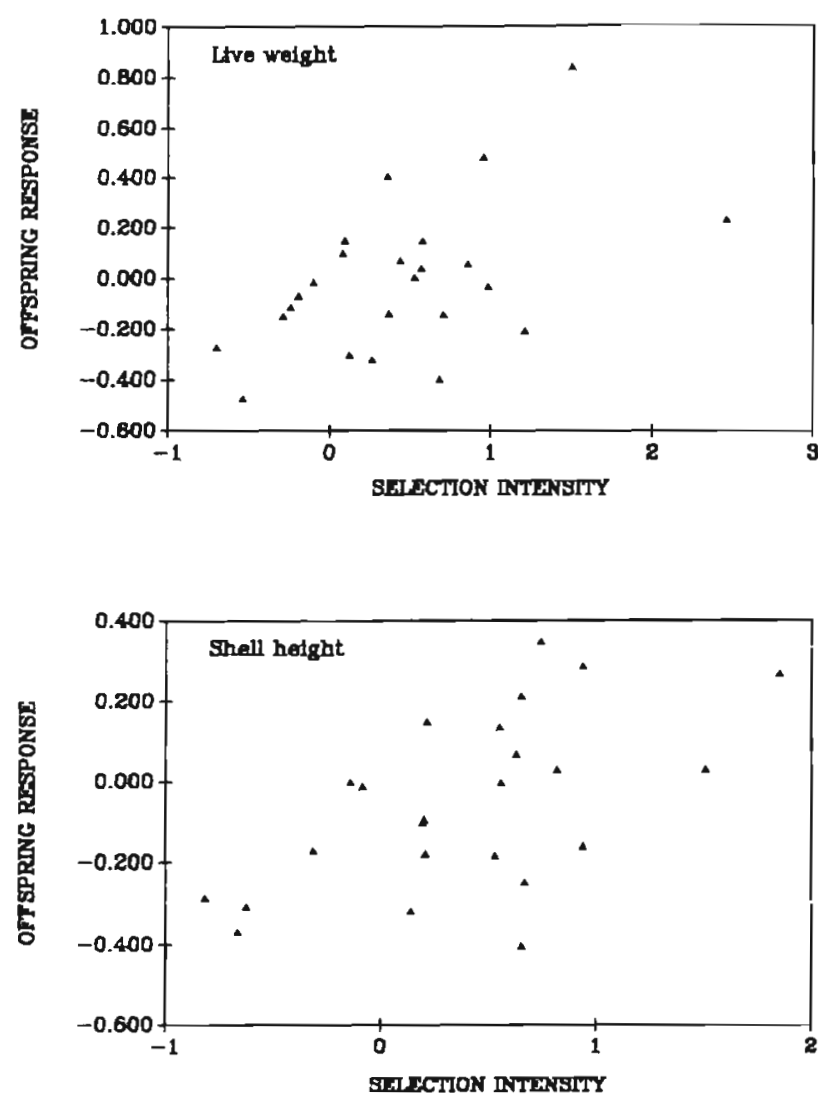

Fig. 2. Ostrea edulis. Plot of standardized response to selection of offspring against selection intensity of parent oysters for the traits live weight and shell height after the second growing season

The pair mating design (Newkirk 1986) used in the present study produced 24 fullsib families. Thirty-one pairs out of 56 spawned $(55 \%)$ and 24 families produced spat ( $43 \%$ ). From the initial 56 pairs, 18 were Low-selected and produced 6 fullsib families ( $33 \%$ ); 38 were High-selected and produced 18 fullsib families $(47 \%)$. In all the families some spat were produced from recently fertilized eggs that were successfully reared (Jarayabhand et al. 1988). Some families were produced from normal larvae and recently fertilized eggs. This difference in the stage of release turned out to have no significant effect on the survival or the growth performance after one growing season (Jarayabhand et al. 1988). The fact that the eggs were in an early stage of division suggests that fertilization had taken place recently and that probably external fertilization may have occurred in some cases. That there is a possibility that external fertilization can be carried out in Ostrea edulis is a result of considerable importance because this would allow a better control of crossing: the production of halfsib families etc.

Within families, there was a tendency, although not significant, for larvae reared from the early release of 
fertilized eggs to have a shorter larvae period, suggesting that larvae developed faster outside the mantle cavity and therefore set before the normal released larvae. Also, the offspring reared from the release of fertilized eggs had a slightly larger (but not significant) mean weight than that obtained from normal larvae (Jarayabhand et al. 1988). This effect was probably associated with a better environment in the rearing tank (food supply, dissolved oxygen content, competition etc.) than inside the mantle cavity of the oyster. Losee (1979) and Newkirk \& Haley (1982b) reported a negative correlation between the length of the larval period and the size of the individuals in the first growing season but later the correlation was close to zero.

The setting of the 24 different families occurred within $35 \mathrm{~d}$. The offspring data was corrected by taking into account the day of set, which had a significant effect on the offspring values $(p<0.01)$. However, the coefficient of determination for the effect of day of set explained less than $2 \%$ of the total variance $\left(\mathrm{R}^{2}=\right.$ $0.013)$.

The $\mathrm{h}^{2}$ estimates for live weight and shell height in the present study for Ostrea edulis are higher than those reported by Ruzzante (1986). In most traits the environmental component of the total variance is larger in early stages of the life cycle than at later stages (i.e. maternal effects) (Gjedrem 1983). Kirpichnikov (1981) and Gjedrem (1983) noted that the coefficient of variation (CV) of body weight and body length decreases with age in fishes. The present study with $O$. edulis shows that the $\mathrm{CV}$ of live weight and shell height decreased from 57.1 to 35.0 and from 29.9 to 20.4 from the first to the second growing season respectively. Therefore the ratio of the additive genetic variance over the total phenotypic variance should increase with age. Increases in $\mathrm{h}^{2}$ have been reported by Kirpichnikov (1981) in common carp Cyprinus carpio, in Atlantic salmon Salmo salar by Refstie \& Steine (1978) and Gjedrem (1983) and in rainbow trout Salmo gairdneri by McKay et al. (1986a). In the present study, the $h^{2}$ estimates in $O$. edulis were higher in the second growing season (1.5-yr-old oysters) with $\mathrm{h}^{2}=0.243$ and 0.194 for live weight and shell height respectively, while during the first growing season the $\mathrm{h}^{2}$ values were 0.136 for live weight and 0.112 for shell height. These relatively low but significant $h^{2}$ estimates for both traits (Table 5) indicate that additive genetic variance for growth rate is present and can be used for improvement through breeding in this population of $O$. edulis.

It is noteworthy that $h^{2}$ for both weight and shell height in this study is reasonably high. Ruzzante (1986) observed much lower heritabilities in the same stock. This may be due to the much higher number of families in the present study; also, Ruzzante selected his parents on basis of $2 \mathrm{yr}$ weight though the parentoffspring regression was done on the first year records. In the present study selection was based on first year parental sizes and, thus, the range in size was quite high.

A significant effect of the nets was detected after the first and second growing seasons (Table 2); however, no environmental pattern in the physical sense was detected (difference between strings or levels). Therefore the environmental effect was random among the nets; different amounts of fouling in each net, as discussed by Ruzzante (1986), could have affected the growth of the juveniles.

A significant response to selection for the selected trait live weight was found during both growing seasons. A correlated response for shell height was detected, suggesting a positive genetic correlation between these traits. The estimated genetic (additive) correlations between live weight and shell height were very high, with $r_{a}=0.963$ and 0.995 during the first and second growing seasons respectively. These estimates suggest pleiotropy among additive genes for shell height and live weight, and that selection for either trait in Ostrea edulis would produce a correlated response in the other. No estimates for such parameters in oysters have been reported previously. Very high genetic correlations (close to unity) between length and weight have been reported in channel catfish Ictalurus punctatus (Reagan et al. 1976), in Atlantic salmon (Refstie \& Steine 1978, Bailey \& Loudenslager 1986) and in rainbow trout (McKay et al. 1986b).

The environmental correlation estimates between the traits live weight and shell height decrease from $r_{e}=0.839$ in the first growing season to $r_{e}=0.670$ in the second growing season, because the heritabilities and hence the additive genetic component of both traits increased in the second growing season.

There were significant phenotypic correlations between live weight and shell height after the first and second growing seasons (Table 3 ). These phenotypic correlation coefficients in both the first and second growing season are in line with those reported by Ruzzante (1986) for Ostrea edulis.

Live weights in the first and second growing seasons are correlated at $r^{2}=0.23(23 \%)$ while the value for shell height is $\mathrm{r}^{2}=0.49(49 \%)$. Thus, the values of live weight and shell height during the first growing season are not very good predictors for the values in the second growing season. The implications to the identification of the superior oysters at the earliest possible stage have been discussed by Newkirk (1981) and Toro \& Newkirk (1989).

The final objective of this selection experiment in Ostrea edulis is the improvement of the stock's growth rate through artificial selection. The $h^{2}$ estimates 
obtained here (under commercial farming conditions) were relatively low but very much in line with livestock traits where selection has been effective in improving economic merit of farm livestock, in experiments and in industrial breeding (Olivier 1987, Smith 1987, Van Vleck 1987). In general body weight shows a higher phenotypic variation in all species of fish and shellfish (Gjedrem 1983) than does body length. The CV for live weight in this study was higher than the CV for shell height, in accordance with this general trend. The improvement of growth rate in this population of $O$. edulis could be achieved by selecting for either of the 2 traits due to the high genetic correlation found between the live weight and shell height. However, due to the higher heritability (larger genetic additive component) and larger phenotypic variation (more selection intensity can be applied) in live weight, it is suggested that this trait should be selected in a breeding program.

Acknowledgements. The study was supported by a Fellowship from the International Development Research Centre and a grant from the National Sciences and Engeneering Research Council. We also thank Dalhousie University for making available the Aquatron facilities.

\section{LITERATURE CITED}

Bailey, J. K., Loudenslager, J. E. (1986). Genetic and environmental components of variation for growth of juvenile Atlantic salmon (Salmon salar). Aquaculture 57: 125-132

Becker, W. A. (1984). Manual of quantitative genetics, 4th edn. Academic Enterprises, Pullman

Falconer, D. S. (1963). Quantitative inheritance. In: Burdette, W J. (ed.) Methodology in mammalian genetics. Holden Day, Inc., San Francisco, p. 193-216

Falconer, D. S. (1981). Introduction to quantitative genetics, 2nd edn. Logman Group Ltd, New York

Gjedrem, T (1983). Genetic variation in quantitative traits and selective breeding in fish and shellfish. Aquaculture 33: $51-72$

Gjerde, B. (1986). Growth and reproduction in fish and shellfish. Aquaculture 57. 37-55

Haley, L. E., Newkirk, G. F., Waugh, D. W., Doyle, R. W. (1976). A report on the quantitative genetics of growth and survivorship of the American oyster, Crassostrea virginica under laboratory conditions. In: Persoone, G., Jaspers, E. (eds.) Proc. 10th Eur Mar. Biol. Symp., Vol. 1 Universa Press, Wetteren, p. 221-228

Haley, L. E., Newkirk, G. F. (1982). The genetics of growth rate of Crassostrea virginica and Ostrea edulis. Malacologia 22: 399-401

Hill, W G. (1971). Design and efficiency of selection experiments for estimating genetic parameters. Biometrics 27 293-311

Hill, W G. (1972). Estimation of realised herutabilities from selection experiments. I. Divergent selection. Biometrics 28: 747-765

Hill, W. G. Thompson, R. (1977). Design of experiments to estimate offspring-parent regression using selected parents. Anim. Prod. 24: 163-168
Jarayabhand, P., Toro, J. E, Fuentes, J. (1988). The European oyster, Ostrea edulis, brooding bivalve? In: Waddy, S. L. (ed.) Proc. Ann. Meet. Aquacult. Ass. Canada, Vol. 2. St. Andrews, p. 69-71

Kempthorne, O., Tandon, O. B. (1953). The estimation of heritability by regression of offspring on parent. Biometrics 9: $90-100$

Kirpichnikov, V. S. (1981). Genetic bases of fish selection. Springer Verlag, Berlin

Lannan, J. E. (1972). Estimating heritability and predicting response to selection for the Pacific oyster, Crassostrea gigas. Proc. natn. Shellfish Ass. 62: 62-66

Longwell, A. C. (1976). Review of genetic and related studies on commercial oysters and other pelecypod mollusks. J. Fish. Res. Bd Can. 33: 1100-1107

Longwell, A. C., Stiles, S. S. (1973). Oyster genetics and the probable future role of genetics in aquaculture. Malacol. Rev. 6: 151-177

Losee, E. (1978). Influence of heredity on larval and spat growth in Crassostrea virginica. Proc. World Maricult. Soc. 9: $101-107$

Losee, E. (1979). Relationship between larval and spat growth rates in the oyster (Crassostrea virginica). Aquaculture 10: 123-126

Mahon, G. A. T. (1983). Selection goals in oyster breeding. Aquaculture 33: 141-148

Mallet, A. L. (1982). Quantitative genetics of the Atlantic Canadian oyster, Crassostrea virginica (Gmelin). Ph.D. thesis, Dalhousie University, Halifax

McKay, L. R., Ihssen, P. E., Friars, G. W (1986a). Genetic parameters of growth in rainbow trout, Salmo gairdneri, as a function of age and maturity. Aquaculture 58: 241-254

McKay, L. R., Ihssen, P. E., Friars, G. W. (1986b). Genetic parameters of growth in rainbow trout, Salmo gairdneri, prior to maturation. Can. J. Genet. Cytol. 28: 306-312

Newkirk, G. F. (1980). Review of the genetics and the potential for selective breeding of commercialy important bivalves. Aquaculture 19: 209-228

Newkirk, G. F. (1981). On the unpredictability of bivalve growth rates: Is a slow growing juvenile oyster a runt for life? In: Claus, C., DePauw, N., Jaspers, E. (eds.) Nursery rearing of bivalve molluscs. Eur. Maricult. Soc. Spec. Publ. $N^{\circ} 7$. EMS, Bredene, Belgium, p. 211-218

Newkirk, G. F. (1986). Controlled mating of the European oyster, Ostrea edulis. Aquaculture 57. 111-116

Newkirk, G. F., Haley, L. E. (1982a). Progress in selection for growth rate in the European oyster Ostrea edulis. Mar. Ecol. Prog. Ser 10:77-79

Newkirk, G. F., Haley, L. E. (1982b). Phenotypic analysis of the European oyster Ostrea edulis L.: relationship between length of larval period and postsetting growth rate. J. exp mar Biol. Ecol. 59: 177-184

Newkirk, G. F., Ilaley, L. E. (1983). Selection for growth rate in the European oyster, Ostrea edulis: response of second generation groups. Aquaculture 33: 149-155

Newkirk, G. F., Haley, L. E., Waugh, D. L., Doyle, R. (1977) Genetics of larvae and spat growth rate in the oyster Crassostrea virginica. Mar Biol. 41-49-52

Ollivier, L. (1987). Current principles and future prospects in selection of farm animals. In: Weir, B. S., Eisen, E. J., Goodman, M. M. Namkoong, G. (ed.) Proc. Second International Conference on Quantitative Genetics. Sinauer Associates, Inc., Sunderland, Massachusetts, p. 438-450

Reagan, R. E., Pardue, G. B., Eisen, E. J. (1976). Predicting selection response for growth of channel catfish. J. Heredity $67 \cdot 49-53$

Refstie, T., Steine, T A. (1978). Selection experiments with 
salmon. III. Genetic and environmental sources of variation in length and weight of Atlantic salmon in the freshwater phase. Aquaculture 14:221-234

Ruzzante, D. E. (1986). Selection for growth rate in the European oyster Ostrea edulis: a multivariate approach. M.Sc. thesis, Dalhousie University, Halifax

Singh, S. M., Zouros, E. (1981). Genetics of growth rate in oysters and its implications for aquaculture. Can. J. Genet. Cytol. 23: 119-130

Smith, C. (1987). Potential for animal breeding, current and future. In: Weir, B. S., Eisen, E. J., Goodman, M. M., Namkoong, G. (eds.) Proc. 2nd International Conference on Quantitative Genetics. Sinauer Associates, Inc., Sunderland, Massachusetts, p. 150-160

Sokal, R. R., Rohlf, F. J. (1981). Biometry, 2nd edn. W. H. Freeman and Co., San Francisco

This article was submitted to the editor
Thorgaard, G. H. (1986). Ploidy manipulation and performance. Aquaculture 57 57-64

Toro, J. E., Newkirk, G. F. (1989). Phenotypic analysis in the Chilean oyster Ostrea chilensis (Philippi 1845): relationship between juvenile and adult growth rates. Aquaculture and Fisheries Management (in press)

Van Vleck, L. D. (1987). Observations on selection advances in dairy cattle. In: Weir, B. S., Eisen, E. J., Goodman, M. M., Namkoong, G. (eds.) Proc. Second International Conference on Quantitative Genetics. Sinauer Associates, Inc., Sunderland, Massachusetts, p. 433-437

Wada, K. T (1986). Genetic selection for shell traits in the Japanese pearl oyster, Pinctada fucata martensii. Aquaculture 57: 171-176

Walne, P. R. (1979). Culture of bivalve molluscs. 50 years experience at Conwy. Fishing News Books Ltd, Farnham

Manuscript first received: July 5, 1989

Revised version accepted: January 19, 1990 